\title{
Announcement Call for Papers: Special Issue of the Clean Air Journal
}

Theme: Air Quality on the South African Highveld

\section{Statement of aims}

The South African Highveld is the most industrialised region in Africa, and is home to around one-third of South Africa's population. Power generation, industrial, mining, transport, residential and other activities emit large amounts of pollutants into the air. Persistent anticyclonic conditions and the dry winter are unfavourable for the dispersion of pollution. Since the National Environmental Management: Air Quality Act was promulgated in 2004, the region has been subjected to numerous air quality management initiatives, including the declaration of the Vaal Triangle Airshed and Highveld Priority Areas.

This special issue of the Clean Air Journal is envisioned to be a synthesis of atmospheric research conducted on the Highveld since 2004, and to provide an update of Tyson, Kruger and Louw (1988). It will be a resource for policy-makers, students, and scientists.

Topics for the special issue include, but are not limited to:

- Atmospheric emissions

- Dispersion climatology

- Trends in and status of ambient air quality

- Impact of air pollution on human health and the physical environment

- Air quality management initiatives

\section{Submissions}

Prospective authors are requested to email their abstract to Dr Gerrit Kornelius (gkornelius@gmail.com) and Dr Kristy Langerman (klangerman@uj.ac.za) prior to writing the full paper, to ensure that the intended paper is within the scope of the special issue. Contributions will also be invited from specific authors.

Authors must submit their papers via the Clean Air Journal's online platform at https://www.cleanairjournal.org.za/about/ submissions. It should be noted in a cover letter that the submission is for the special issue "Air Quality on the South African Highveld." If the manuscript is not intended as an original research paper, the cover letter should also specify if it is, rather, a review paper or commentary.

The final date for submission of full papers is 31 May 2021.

\section{Peer review process}

All submitted papers must be original and will go through the Clean Air Journal's rigorous blind peer-review process with at least two reviewers. The CAJ's editorial policy will be strictly followed by special issue reviewers. The final decision on the acceptance of papers for publication remains with the Editorsin-Chief of the Clean Air Journal.

Accepted papers will be published immediately in an Online Early edition of the special issue. The special issue will be published online in November/December 2021. If sponsors can be found, there will also be a print version of the special issue.

\section{Guest editors}

Elizabeth Masekoameng, GIZ

EMasekoameng@yahoo.com

Dr Gerrit Kornelius, University of Pretoria

gkornelius@gmail.com

Sean O'Beirne, SE Solutions

sobeirne@tiscali.co.za

\section{Questions regarding the special issue}

Please direct any questions to Kristy Langerman at klangerman@uj.ac.za.

\section{References}

Tyson, P.D., Kruger, F.J. and Louw, C.W. (eds), 1988: Atmospheric Pollution and its Implications in the Eastern Transvaal Highveld, South African National Scientific Programmes Report No. 150, Council for Scientific and Industrial Research, Pretoria 